\title{
PENERAPAN PRINSIP-PRINSIP GOOD GOVERNANCE DALAM PELAYANAN PUBLIK DI RSUD LANTO DAENG PASEWANG KABUPATEN JENEPONTO
}

\author{
Mukhtar Tompo ${ }^{1}$, Muhlis Madani $^{2}$, Fatmawati $^{3}$ \\ 1,2,3 Universitas Muhammadiyah Makassar, Indonesia \\ e-mail: ${ }^{1}$ mukhtar.tompo7@gmail.com, ${ }^{3}$ fatmamappasere@gmail.com
}

\begin{abstract}
Abstrak
The purpose of this study is to describe and analyze the application of the principles of good governance in public services, the supporting and inhibiting factors for the application of the principles of good governance, and the output of public services at the Lanto daeng Pasewang Regional General Hospital, Jeneponto Regency. This research uses qualitative research. The instrument used in this study was the interview with the informant, then the answers from the informants were analyzed and described descriptively. The results show that the implementation of good governance related to participation has been carried out, but there is still something that needs to be invited to participate, namely community participation (NGO), related to transparency has not been fully implemented, related to responsiveness has not been implemented, related to accountability is not applied by the management of Lanto Daeng Pasewang Regional Hospital. . Supporting factors in the process of implementing the principles of good governance are the factors of cooperation and communication factors. The output of the service system at Lanto Daeng Pasewang Regional Hospital has not been effective in implementing the service standards of the RSUD considering that the administration is still slow and is still waiting for days to get the results of the examination.
\end{abstract}

Keywords: Good Governance (GUG), Public Services

\begin{abstract}
Abstrak
Tujuan penelitian ini untuk Mendeskripsikan dan menganalisis penerapan prinsip-prinsip good governance dalam pelayanan publik, faktor pendukung dan penghambat penerapan prinsip-prinsip good governance, dan output pelayanan publik di Rumah Sakit Umum Daerah Lanto daeng Pasewang Kabupaten Jeneponto. Penelitian ini menggunakan penelitian kualitatif. Instrumen yang digunakan dalam penelitian ini adalah wawancara dengan informan selanjutnya jawaban dari informan dianalisis dan dijabarkan secara deskriptif. Hasil penelitian menunjukkan bahwa Penerapan good governance terkait partisipasi sudah terlaksana, namun masih ada yang perlu diajak untuk berpartisipasi yakni partisipasi Masyarakat (NGO), terkait transparansi belum terlaksana sepenuhnya, terkait daya tanggap belum terlaksana, terkait akuntabilitas tidak diterapkan oleh pihak manajemen RSUD Lanto Daeng Pasewang. Faktor pendukung dalam proses penerapan prinsip-prinsip good governance adalah faktor kerjasama dan faktor komunikasi. Output sistem pelayanan di RSUD Lanto Daeng Pasewang belum efektif dalam melaksanakan standar pelayanan RSUD mengingat pengurusan administrasi masih lambat serta masih menunggu berhari-hari untuk mendapatkan hasil pemeriksaan.
\end{abstract}

Kata Kunci: Good Governance (GUG), Pelayanan Publik

\section{PENDAHULUAN}

Pemerintah telah mengeluarkan UU No 25 Tahun 2009 yang mengatur terkait pelayanan publik, pada Pasal 3 disebutkan salah satu tujuan pelayanan publik yaitu terwujudnya batasan dan hubungan yang jelas tentang hak, tanggungjawab, kewajiban dan kewenangan seluruh pihak yang terkait dengan pelaksana pelayanan publik. Selain itu, tujuan lainnya yakni terbentuknya sistem pelaksanaan pelayanan publik yang layak sebagaimana asas umum pemerintahan dan korporasi yang baik .

Peningkatan kualitas pelayanan publik, juga merupakan alasan terbitnya kebijakan desentralisasi, yang merupakan produk hukum era reformasi. Produk tersebut antara lain Undang-undang Pemerintah Daerah No. 22/ 1999 dan No. 25/ 1999 yang kemudian direvisi menjadi Undang-undang No. 32/2004 tentang 
Pemerintahan Daerah kemudian direvisi kembali dengan Undang-Undang No. 9/2015 tentang Pemerintahan Daerah. Melalui Undang-undang tersebut, pemerintah pusat mendelegasikan wewenangnya kepada pemerintah kabupaten/kota. Kebijakan otonomi tersebut, menuntut pemerintah daerah menjadi mandiri dan kreatif dalam menjalankan roda pemerintahan demi meningkatkan kesejahteraan rakyat di daerah tersebut. Kebijakan ini memunculkan harapan, melalui otonomi kabupaten/kota ini diharapkan pemerintah semakin dekat kepada masyarakat, agar pelayanan kepada masyarakat semakin baik. Selain itu, beban pemerintah pusat semakin berkurang dalam meningkatkan kemandirian, kedewasaan, serta kreativitas pemerintah daerah.

Jika ditilik dari tujuan otonomi daerah yaitu mendekatkan pelayanan publik kepada masyarakat, pelayanan publik pemerintah diharapkan berjalan lebih efektif dan efisien. Asumsi dasarnya, pemerintah daerah lebih memahami kebutuhan masyarakat. Pelayanan publik di era Otonomi Daerah diharapkan pula dijalankan secara lebih fleksibel dan inovatif, sehingga menghasilkan semangat kerja dan komitmen yang lebih tinggi, serta lebih produktif karena dapat memberi respon lebih cepat terhadap lingkungan ataupun kebutuhan masyarakat yang berubah.

Konsep good governance dipopulerkan pertama kali oleh lembaga donor internasional seperti World Bank, UNDP, dan IMF pada penghujung tahun 1980-an (Mardiasmo, 2009). Konsep good governance memberikan rekomendasi pada sistem pemerintahan yang berorientasi kesetaraan antar lembaga publik di tingkat pusat maupun daerah, sektor swasta, serta masyarakat sipil (civil society). Dengan penerapan good governance, diharapkan mampu menjamin pelaksanaan fungsi pelayanan pemerintah sekaligus pemberdayaan sektor non pemerintah dalam pembangunan. Ide pokoknya, fungsi serving dari pelayanan publik tetap berjalan, meskipun pemainnya bergeser ke sektor swasta; bagaimana aparatur dan birokrasi pemerintah menjalankan fungsi pelayanan dengan tetap menjunjung prinsipprinsip seperti keadilan, pemerataan dan kepantasan, khususnya bagi masyarakat marginal.

Penempatan di posisi baru, pegawai ditempatkan diposisi baru dengan surat keputusan dan deskripsi tugas barunya. Manajer SDM mungkin harus memberikan briefing mengenai posisi baru tersebut, hak dan kewajibannya serta deskripsi tugas serta kinerja yang diharapkan. Evaluasi pelaksanaan karier, pegawai dievaluasi kinerjanya secara periodik mengenai pelaksanaan jabatan barunya (Wirawan, 2015:432).

Persoalan yang terjadi dalam pelayanan kesehatan, antara lain masih adanya keluhan pasien yang merasa belum memeroleh pelayanan yang baik dan adil dari petugas rumah sakit, pelayanan administrasi dengan birokrasi yang berbelit, maupun kualitas obat yang didapatkan pasien tidak memadai (Handayani, 2016). Kasus-kasus tersebut juga pernah terjadi di Rumah Sakit Lanto Daeng Pasewang Kabupaten Jeneponto. Sekitar awal bulan Mei 2019, masyarakat Jeneponto banyak mengeluhkan pelayanan rumah sakit tersebut yang lumpuh karena stok obat-obatan habis. Akibatnya, warga tidak dapat mengakses layanan kesehatan. Banyak pula pasien yang sementara dalam perawatan, akhirnya dirujuk ke Rumah Sakit di daerah lain seperti Rumah Sakit Umum Daerah Kabupaten Bantaeng dan Rumah Sakit Umum Daerah Kabupaten Takalar. Saat itu, solusi yang ditempuh oleh Bupati Jeneponto untuk memulihkan kondisi rumah sakit yakni dengan menonaktifkan Direktur Rumah Sakit Umum Daerah Kabupaten Jeneponto, dan melantik Direktur Rumah Sakit yang baru (www.ombudsman.go.id, diakses 30 Oktober 2020). Namun pergantian Direktur tidak membawa perubahan signifikan pada manajemen rumah sakit. Sekitar bulan Maret 2020, atau hampir setahun setelah peristiwa kekosongan obat, Rumah Sakit Lanto Dg Pasewang Kabupaten Jeneponto Kembali dilanda masalah berat. Masalahnya berupa minimnya ketersediaan alat pelindung diri (APD) di tengah pandemi Covid-19.

Selain berangkat dari persoalan empirik tersebut, penelitian ini juga merupakan upaya memperkuat kajian seputar penerapan good governance dalam pelayanan publik. Penelitian yang terkait dengan implementasi Good Governance dalam berbagai sektor pelayanan publik telah dilakukan sejumlah peneliti terdahulu. Penelitian di berbagai sektor tersebut, antara lain di bidang layanan pemerintahan (Safrijal dkk, 2016; Adianto dkk, 2017), bidang pendidikan (Muljo dkk, 
2014), bidang keagamaan (Fadilah, 2011), dan bidang kesehatan (Merita, 2015; Handayani, 2016). Penelitian ini memiliki beberapa persamaan dengan kajian Merita dan Handayani. Namun kajian Merita (2015) difokuskan melihat implementasi UU No 25/2009, sedangkan good governance hanya dilihat sebagai implikasi jika UU tersebut dijalankan. Riset yang akan peneliti lakukan memang difokuskan untuk melihat sejauh mana penerapan prinsip-prinsip good governance di rumah sakit. Sementara itu, riset Handayani (2016) hanya fokus pada penerapan dua prinsip good governance, yakni transparansi dan akuntabilitas. Obyek penerapan yang dikaji pun tebatas pada Instalasi Gawat Darurat rumah sakit. Studi yang akan peneliti lakukan yaitu mengkaji penerapan empat dari sembilan prinsip good governance menurut UNDP, yaitu partisipasi, transparansi, daya tanggap dan akuntabilitas. Obyek yang dikaji dalam ruang lingkup manajemen rumah sakit secara keseluruhan. Selain itu, obyek material penelitian ini adalah RSUD Lanto Daeng Pasewang Kabupaten Jeneponto, yang berbeda dengan obyek kajian penelitian-penelitian sebelumnya.

Berdasarkan persoalan lapangan maupun keterbatasan penelitian terdahulu tersebut, peneliti tertarik mengkaji penerapan prinsipprinsip good governance dalam pelayanan publik di RSUD Lanto Daeng Pasewang Kabupaten Jeneponto.

\section{KAJIAN LITERATUR}

\section{Pengertian Good Governance}

Secara bahasa, governance berasal dari bahasa Francis kuno "gouvernance" yang artinya control yakni suatu keadaan yang terkendali (the state of being governed) (Syakhroza, 2005), atau dari bahasa Latiin "gubernare" ada juga dari bahasa Yunani "kyibernan" yang berarti to steer, guide atau govern (Iqbal dan Lewis, 2009). Governance dirujuk dari proses pemerintahan, baik yang dilakukan oleh pemerintah, pasar atau jaringan, baik melalui keluarga, suku, organisasi formal atau informal atau wilayah dan baik melalui hukum, norma-norma, kekuasaan atau bahasa (Wikipedia.com) . Governance adalah sebuah konsep yang highly contextual yang mana teori dan definisinya tergantung pada konteksnya (Carrington dkk, 2008, www.iog.com, 2011), sehingga mempunyai terminologi yang bermacam-macam misalnya monetary governance, economic governance, public governance, corporate governance (Iqbal dan Lewis,2009) .

Good Governance (GG) adalah sesuatu yang berbeda, GG adalah konsep partisipatif, transparan dan akuntabel, ia juga menyangkut efektifitas dan keadilan serta mengedepankan aturan hukum yang jelas (European Journal of Humanities and Social Sciences Vol. 27 No.1 2013). Merujuk dokumen kebijakan Austrian bahwa GG adalah bentuk manajemen yang transparan dan dapat dipertanggungjawabkan terhadap penggunaan sumber daya manusia, sumber daya alam, dan sumber ekonomi dan keuangan dengan maksud tercapainya keadilan dan pengembangan berkelanjutan (Federal Ministry, 2011) . Dalam perspektif sebuah disiplin tata kelola merupakan model teoritis dari negara ideal dan bagaimana cara menjalankannya secara tepat . Berlandaskan pandangan ini semua model tata kelola dilihat berakar dari kerangka konseptual yang sama. Selanjutnya dalam perspektif checks and balances, tata kelola merupakan proses delegasi wewenang untuk pengambilan keputusan. Proses delegasi membutuhkan adanya checks and balances terhadap otoritas yang diberi wewenang untuk membuat keputusan. Dalam perspektif pengambilan keputusan, tata kelola terkait dengan efektifitas keputusan yang dibuat (Iqbal dan Lewis, 2009) . Ketika terkait dengan efektivitas pembuatan keputusan tata kelola merupakan structure of relationships that bring about organisational coherence, authorise policies, plans and decisions, and account for their probity, responsiveness and cost- effectiveness (Gallagher 2001:1 dalam Cumming dkk, 2007) .

Good Governance sering dimaknai sebagai tata pemerintahan yang baik . Dalam defenisi Bank Dunia (dalam Mardiasmo, 2009:18), good governance merupakan suatu penyelenggaraan manajemen pembangunan yang solid dan bertanggung jawab yang sejalan dengan prinsip demokrasi dan pasar yang efisien, penghindaran salah alokasi dana investasi, dan pencegahan korupsi baik secara politik maupun administratif, menerapkan 
disiplin anggaran, serta penciptaan legal dan political framework bagi pertumbuhan aktivitas usaha

\section{Prinsip-prinsip Good Governance}

Program Pembangunan Dunia PBB atau United Nations Development Programme (UNDP) (dalam Adianto, dkk., 2017:4-5) mengajukan 9 prinsip good governance sebagai berikut:

a. Participation

Setiap warga negara memiliki suara dalam pengambilan keputusan, baik secara langsung ataupun melalui intermediasi institusi yang mewakili kepentingan mereka . Partisipasi semacam ini dibangun atas dasar kebebasan berserikat, berbicara, dan berpartisipasi secara konstruktif .

b. Rule of Law

Aturan hukum harus dilaksanakan secara adil dan tanpa pandang bulu, khususnya hukum untuk Hak Asasi Manusia (HAM) .

c. Transparency

Transparansi dibangun atas dasar kebebasan informasi. Setiap proses, lembaga dan informasi secara langsung bisa diterima oleh mereka yang membutuhkan. Informasi mesti dapat dipahami dan dimonitor .

d. Responsiveness

Lembaga-lembaga dan proses-proses harus tanggap dalam melayani setiap pemangku kepentingan (stakeholders) .

e. Consensus Orientation

Good governance dapat menjadi perantara beragam kepentingan yang berbeda dalam rangka memeroleh pilihan terbaik demi kepentingan yang lebih luas, baik menyangkut kebijakan maupun prosedur .

f. Equity

Semua warga negara mempunyai kesempatan meningkatkan atau menjaga kesejahteraan mereka .

g. Effectiveness and Efficiency

Setiap tahapan proses serta lembagalembaga mesti menghasilkan sesuai dengan target, dan memanfaatkan sumber yang tersedia sebaik mungkin .

h. Accountability

Para pengambil kebijakan dalam pemerintahan, termasuk sektor swasta ataupun masyarakat sipil (civil society) bertanggungjawab kepada publik dan para lembaga pemangku kepentingan (stakeholders) . Akuntabilitas sangat bergantung pada organisasi dan sifat keputusan yang dikeluarkan, apakah keputusan itu demi kepentingan internal atau eksternal organisasi .

i. Strategic Vision

Para pemimpin dan publik mesti memiliki perspektif good governance dan pengembangan manusia yang jauh ke depan, sejalan dengan apa yang dibutuhkan untuk pembangunan .

\section{Konsep Pelayanan Publik}

Pelayanan sebagai proses pemenuhan kebutuhan melalui aktivitas orang lain secara langsung (Napitupulu, 2007:17) merupakan konsep yang senantiasa aktual dalam berbagai aspek kelembagaan. Pelayanan publik atau public services untuk masa sekarang ini masih menjadi persoalan yang perlu memperoleh perhatian dan penyelesaian yang komprehensif, hal ini dibuktikan ketika timbul berbagai tuntunan pelayanan publik sebagai tanda ketidakpuasan masyarakat .

Menurut Albercht dalam Lovelock, 1992 (dalam Sedarmayanti 2010:243) pelayanan adalah suatu pendekatan organisasi total yang menjadi kualitas pelayanan yang diterima pengguna jasa, sebagai kekuatan penggerak utama dalam pengoperasian bisnis.

Selanjutnya Monir (dalam Harbani Pasolong 2013: 128), mengatakan bahwa pelayanan adalah proses pemenuhan kebutuhan melalui aktivitas orang lain secara langsung. Sedangkan Menteri Pendayagunaan Aparatur Negara mengemukakan bahwa, pelayanan adalah segala bentuk kegiatan pelayanan dalam bentuk barang atau jasa dalam rangka upaya pemenuhan kebutuhan masyarakat .

Sedangkan menurut Gronroos (dalam Ratminto dan Atik Septi Winarsih 2013:2) pelayanan adalah suatu aktivitas atau serangkaian aktivitas yang bersifat tidak kasat mata (tidak dapat diraba) yang tejadi sebagai akibat adanya interaksi antara konsumen dengan karyawan atau hal-hal lain yang disediakan oleh perusahaan pemberi pelayanan yang dimaksudkan untuk memecahkan permasalahan konsumen/ pelanggan. 
Pelayanan publik adalah pemberian jasa, baik oleh pemerintah, pihak swasta atas nama pemerintah, ataupun pihak swasta kepada masyarakat, dengan atau tanpa pembayaran guna memenuhi kebutuhan dan atau kepentingan masyarakat (Panji Santosa 2009:57) . Menurut Thoha (dalam Sedarmayanti 2010:243) pelayanan masyarakat adalah usaha yang dilakukan oleh seseorang dan atau kelompok orang atau instansi tertentu untuk memberi bantuan dan kemudahan kepada masyarakat dalam mencapai tujuan.

\section{Prinsip-Prinsip Pelayanan Publik}

Menurut Surjadi (2009), Penyelenggaraan pelayanan publik juga harus memperhatikan prinsip- prinsip penyelenggaraan pelayanan publik:

1) Kesederhanaan: prosedur pelayanan publik tidak berbelit-belit atau cepat, mudah dipahami, dan mudah dilaksanakan.

2) Kejelasan yakni: Persyaratan teknis dan administrasi pelayanan publik dan Unit kerja/pejabat yang berwenang dan bertangungjawab dalam memberikan pelayanan dan penyelesaian keluhan/ persoalan/ sengketa dalam pelayanan publik.

3) Kepastian dan tepat waktu; pelaksanaan pelayanan publik dapat diselesaikan dalam kurun waktu yang sudah ditetapkan.

4) Akurasi; produk pelayanan publik diterima dengan benar, tepat, dan sah.

5) Tidak diskrimantif; yakni tidak membedakan suku, ras, agama, golongan, gender, dan strata ekonomi.

6) Bertanggungjawab; pimpinan penyelenggara pelayanan publik atau pejabat yang ditunjuk bertanggungjawab atas penyelenggaraan pelayanan dan penyelesaian keluhan/persoalan dalam pelaksanaan pelayanan publik.

7) Kelengkapan sarana dan prasarana; tersedianya sarana dan prasarana kerja, peralatan kerja dan pendukung lainnya yang memadai termasuk penyediaan sarana teknologi telekomunikasi dan informatika.

8) Kemudahan akses; tempat dan lokasi serta sarana pelayanan yang memadai, mudah dijangkau oleh masyarakat dan dapat memanfaatkan teknologi

komunikasi dan informasi.

9) Kejujuran;

10) Kecermatan;

11) Kedislipinan, kesopanan, dan keramahan; aparat penyelenggara pelayan harus displin, sopan, ramah, dan memberikan pelayanan dengan ikhlas sehinga penerima layanan merasa dihargai hakhaknya.

12) Memberikan rasa aman dan nyaman dan kepastian hukum.

\section{Standar Pelayanan Publik}

Setiap penyelenggaraan atau penyediaan pelayanan publik haruslah memiliki standarisasi dalam pelayanannya. Selanjutnya stadarisasi pelayanan publik tersebut perlu dipublikasikan agar dapat diakses atau diketahui oleh masyarakat sebagai pengguna pelayanan publik. Standar pelayanan publik dimaknai sebagai suatu ukuran yang telah ditentukan oleh penyelenggara atau penyedia pelayanan publik sehingga nantinya wajib ditaati oleh pemberi dan atau penerima pelayanan .

Surjadi (2009:69) mengatakan bahwa standar pelayanan publik sekurang-kurangnya meliputi beberapa hal yaitu:

1) Prosedur pelayanan yang diberikan bagi pemberi dan penerima pelayanan termasuk pengaduan.

2) Waktu penyelesaian yang ditetapkan sejak saat pengajuan permohonan sampai dengan penyelesaian pelayanan termasuk pengaduan.

3) Biaya/tarif pelayanan termasuk rinciannya yang ditetapkan dalam proses pemberian pelayanan.

4) Hasil pelayanan yang akan diterima sesuai dengan ketentuan yang telah ditetapkan.

5) Penyediaan sarana dan prasarana pelayanan yang memadai oleh penyelenggara pelayanan publik.

6) Kompetensi harus ditetapkan dengan tepat berdasarkan pengetahuan, keahlian, keterampilan, sikap, dan perilaku yang dibutuhkan.

\section{METODE PENELITIAN}

Jenis penelitian ini yakni penelitian kualitatif. Unit analisis penelitian yakni 
penerapan good governance pada RSUD Lanto Daeng Pasewang Jeneponto. Subjek Penelitian ini adalah prinsip-prinsip Good Governance di RSUD Lanto Pasewang Kabupaten Jeneponto dan penerapannya dalam upaya untuk mewujudkan pelayanan publik.

\section{HASIL PENELITIAN}

\section{Sejarah Ringkas RSUD Lanto Daeng Pasewang}

Rumah Sakit Umum Daerah (RSUD) Lanto Daeng Pasewang Kab. Jeneponto berdiri pertanggal 18 Januari tahun 1990 dibawah bantuan dari Foster Parents Plan International, serta pelaksana pada proses pembangunannya, Rumah Sakit ini dikerjakan oleh PT. Adi Jaya Lima Pradana dan disahkan oleh Menkes RI pada waktu itu yakni Bapak Dr. Adhyatma., M.P.H. Alasan penamaan Lanto Daeng Pasewang karena almarhum pernah berdomisil di Kabupaten Jeneponto serta menuntaskankan pendidikannya di Inlandsche School di Jeneponto. Lanto Daeng Pasewang lahir tanggal 03 Juli Tahun 1900. Ayahnya yaitu Djangkang Daeng Lili sedangkan Ibunya yaitu Sulo Daeng Siolo. Pada tahun 1920, beliau menyelesaikan sekolahnya di Osvia Makassar. Lanto Daeng Pasewang diangkat menjadi Gubernur Sulawesi yang ke III pada tanggal 09 November 1953. Perkembangan dan kemajuan RSUD Lanto Daeng Pasewang secara fisik sudah dianggap mengalami kemajuan. Namun dari segi type, RSUD Lanto Daeng Pasewang masih tergolong ke dalam Rumah Sakit tipe C.

Penerapan prinsip-prinsip good governance dalam pelayanan public pada RSUD Lanto Daeng Pasewang Kab. Jeneponto dilihat dari aspek partisipasi, transparansi, daya tanggap dan akuntabilitas

Good governance menurut organisasi Program Pembangunan PBB atau United Nations Development Program (UNDP) adalah praktek pelaksanaan kewenangan pengelolaan berbagai urusan penyelenggara negara secara politik, ekonomi dan administratif di semua tingkatan. Konsep tersebut mengandung makna bahwa good governance mempunyai 3 pilar yang urgen, yakni 1) Economic governance (kesejahteraan Rakyat); 2) Political governance (Proses pengambilan keputusan); 3) Administrative governance (tata laksana implementasi kebijakan) .

Peneliti memberi batasan atau defenisi good governance sebagai sebuah penyata laksanaan berbagai konsep pemerintah ke dalam bentuk yang sebenarnya, dalam arti bahwa apa yang menjadi konsep atau program pemerintah yang baik tersebut dapat dirasakan manfaatnya bagi semua lapisan masyarakat baik dalam aspek ekonomi, politik maupun aspek pelayanan publik.

Berikut ini akan dijelaskan 4 (empat) prinsip Good governance yakni partisipasi, transparansi, daya tanggap, dan akuntabilitas.

\section{a. Partisipasi}

Partisipasi oleh pria dan wanita adalah kunci good governance. Partisipasi dapat langsung maupun melalui institusi perwakilan yang legitimate. Partisipasi harus informatif dan terorganisir. Hal ini mensyaratkan adanya kebebasan berasosiasi dan berekspresi di satu sisi dan sebuah civil society yang kuat dan terorganisir di sisi lain.

Berdasarkan hasil wawancara dari para narasumber, maka dapat disimpulkan bahwa dalam proses penyusunan anggaran terkait dengan partisipasi pihak-pihak yang terlibat dalam menyusun anggaran secara aturan sudah tepat yakni melibatkan Direktur, Direksi, unitunit instalasi, bagian keuangan dan terakhir pengesahannya di DPRD Kabupaten Jeneponto. Meskipun dalam pandangan lain masyarakat meminta tetap ada keterlibatan (partisipasi) masyarakat (NGO) dalam proses penyusunan anggaran.

\section{b. Transparansi}

Keterbukaan pelayanan public atau transparansi adalah sebuah hal yang mesti segera diciptakan agar dapat menciptakan keberhasilan otoda (otonomi daerah) serta memenangkan pertarungan pada masa sekarang ini. selebihnya, transparansi menjadi sebagai sebuah prinsip untuk mewujudkan good governance (pemerintahan yang baik).

Ketersediaan informasi yang akurat, relevan serta mudah dimengerti bisa didapatkan secara low-cost atau rendah biaya sehingga stakeholder bisa mengambil 
keputusan yang baik merupakan intisari dari transparansi. Proses pengambilan keputusan dan implementasi keputusan tersebut dilakukan dalam tata cara yang tetap mengikuti kaidah hukum dan peraturan negara. Informasi tersebut harus tersedia secara bebas (transparan) dan dapat diakses langsung oleh publik. Informasi yang disediakan harus dalam bentuk media yang mudah dipahami dan mudah dimengerti.

Menjadi sebuah keharusan bagi semua Rumah Sakit baik yang dikelola oleh Negara maupun yang dikelola oleh swsata untuk memberikan ketersediaan informasi bagi para pihak yang berkepentingan dalam hal ini kepada masyarakat umum sebagai pengguna jasa layanan.

Salah satu bentuk dari transparansi yang dilakukan oleh Rumah Sakit adalah dengan membuat sebuah sitem informasi baik sistem informasi layanan rumah sakit, sistem informasi akuntansi dan pelaporan keuangan yang mudah diakses dan transparan bagi masyarakat yang membacanya.

Berdasarkan apa yang disampaikan oleh Direktur RSUD Lanto Daeng Pasewang dan tokoh masyarakat Kabupaten Jeneponto maka dapat dikatakan bahwa untuk sistem informasil layanan rumah sakit telah diusahakan keberadaannya yaitu dengan diluncurkannya aplikasi Pasien dan antrian Mandiri RSUD Lanto Daeng Pasewang. Namun untuk sistem informasi terkait anggaran belum ada dan masih dalam tahap diusahakan.

\section{c. Daya Tanggap}

Salah satu prinsip good governance yang terjadi di rumah sakit yakni pihak manajemen rumha sakit dalam hal ini pimpinannya harus responsif terhadap keperluan masyarakat (Calon Pasien dan pasien). Manajemen RSUD Lanto Daeng Pasewang dianggap belum responsif dimana daya tanggapnya yang berkaitan dengan pelayanan mampu untuk mengatasi permaslaahan di rumah sakit. Seperti misalnya kelangkaan obat dan alat kesehatan belum mampu sepenuhnya ditangani oleh pihak Manajemen RSUD Lanto Daeng Pasewang.

Penerapan prinsip daya tanggap dalam tata kelola Manajemen RSUD Lanto Daeng Pasewang dapat dilihat dari lambatnya pelayanan kepada masyarakat / pasien yang diberikan oleh Manajemen RSUD Lanto
Daeng Pasewang. Dalam melakukan pelayanan kepada pasien, Manajemen RSUD Lanto Daeng Pasewang tidak memberikan pelayanan kepada masyarakat / pasien seperti terlantarnya pasien akibat tidak mendapat obat-obatan. Hal tersebut terjadi akibat tidak adanya stok obat-obatan di RSUD Lanto Daeng Pasewang bahkan hal tersebut berujung kepada pencopotan direktur Rumah Sakit yang lama (dr. Iswan Sanabi) kemudian digantikan oleh yang baru (drg. Bustamin).

Berdasarkan hasil wawancara dapat disimpulkan bahwa kondisi tersebut membuat Manajemen RSUD Lanto Daeng Pasewang dianggap belum memiliki daya tanggap yang baik terhadap kebutuhan pasien yakni pelayanan kesehatan dan ketersediaan obatobatan. Hal lainnya adalah Manajemen RSUD Lanto Daeng Pasewang belum menyediakan bagaimana mekanisme dan prosedur pengaduan. Belum tersedianya kotak saran atau fasilitas lainnya yang mendukung pengaduan masyarakat / pasien menjadi bukti bahwa Manajemen RSUD Lanto Daeng Pasewang belum sepenuhnya dapat menerapkan prinsip daya tanggap.

\section{d. Akuntabilitas}

Akuntabilitas dalam konsep good governance adalah berkaitan dengan tanggungjawab atas manajemen rumah sakit terhadap pihak pemerintah, sesuai dengan peraturan yang berlaku. Laporan good governance dalam organisasi seperti rumah sakit biasanya ada temuan bahwa laporannya yang saling tumpang tindih sehingga sulit untuk mengidentifikasikan tujuan strategis organisasi secara tepat.

Sebagai bentuk komitmen dan tanggungjawab untuk mengimplementasikan salah satu indikator dari good governace yakni akuntabilitas, Rumah Sakit Umum Daerah Lanto Daeng Pasewang berupaya untuk menyusun laporan keuangan sebagai upaya untuk mewujudkan good university governace tersebut.

Berdasarkan hasil wawancara dengan para narasumber, dapat disimpulkan bahwa penerapan prinsip good governance terkait akuntabilitas tidak diterapkan oleh pihak manajemen Rumah Sakit Umum Lanto Daeng Pasewang. Tidak adanya keterbukaan terkait anggaran, proses penyusunannya yang tidak transparan hingga berakibat kepada 
tersangkanya bendahara rumah sakit mencerminkan bahwa akuntabilitas tidak terlaksana di RSUD Lanto Daeng Pasewang.

\section{Faktor pendukung dan penghambat}

Berikut ini adalah Faktor pendukung dan penghambat penerapan prinsip-prinsip good governance dalam pelayanan publik di Rumah Sakit Umum Daerah Lanto Daeng Pasewang Kabupaten Jeneponto :

\section{a. Faktor Pendukung}

Faktor-faktor pendukung dalam penerapan Good Governance adalah: 1) Kerjasama ; Kerjasama yang terjalin baik antara pihak manajemen rumah sakit dengan masyarakat dan stakeholder merupakan faktor yang paling menentukan. Proses penerapan prinsip-prinsip good governance seperti partisipasi, transparansi, daya tanggap dan akuntabilitas tentunya hanya bisa terlaksana jika kerjasama terbanung dengan baik antara manajemen rumah sakit Lanto Daeng Pasewang, masyarakat, dan pihak stakeholder. 2) Komunikasi ; Komunikasi merupakan sarana yang paling baik dalam proses penerapan prinsip-prinsip good governance. Komunikasi yang baik akan melahirkan pola pelayanan yang baik dari rumah sakit kepada masyarakat.

Bustamin yang mengatakan bahwa Faktor pendukung DI RSUD Lanto Daeng Pasewang adalah dapat terjadi jika terbangun komunikasi yang baik antara kamisebagai penyedia layanan kesehatan dengan masyarakat sebagai penerima layanan kesehatan, jika ini terjalin dengan baik maka akan memudahkan proses penerpan prinsip-prinsip good governance yang dimakasud yakni partisipasi, transparansi, daya tanggap dan akuntabilitas.

Berdasarkan hal tersebut di atas maka dapat disimpulkan bahwa faktor pendukung dalam proses penerapan prinsip-prinsip good governance adalah faktor kerjasama dan faktor komunikasi.

Berdasarkan apa yang disampaikan oleh direktur rumah sakit maka dapat disimpulkan bahwa salah satu faktor yang dapat mendukung dalam proses pelayanan di RSUD Lanto Daeng Pasewanng adalah adanya kerjasama.

\section{b. Faktor Penghambat}

Dalam penerapan prinsip-prinsip Good Governance di RSUD Lanto Daeng Pasewang Kabupaten Jeneponto banyak terdapat kendala-kendala yang sangat menghambat kelancaran dalam proses pelayanan. Beberapa diantaranya yaitu fasilitas pelayanan yang kurang memadai hal ini di sebabkan kerena keterbatasan dana, sehingga Pihak RSUD agak kesulitan dalam melaksanakan pelayanan, saat ini manajemen hanya memanfaatkan fasilitas yang ada dalam melaksanakan tugas pelayanan.

Sebagaimana yang dijelaskan oleh Direktur Rumah Sakit Daerah Lanto Daeng Pasewang bapak drg. Bustamin yang mengatakan bahwa Faktor penghambat DI RSUD Lanto Daeng Pasewang adalah minimnya fasilitas rumah sakit yang sesuai standar mengingat RSUD Lanto Daeng Pasewang belum naik status menjadi Rumah Sakit BLUD (Badan Layanan Umum Daerah) dengan demikian fasilitas yang ada belum mampu untuk memberikan kepuasan pelayanan sesuai standar rumah sakit swasta yang berada di daerah lain.

Berdasarkan fenomena tersebut, hal ini sesuai dengan yang disampaikan oleh Purwanto (2008:190) "Pada pelayanan publik, prinsip partisipasi dalam upaya mewujudkan Good Governance, sejalan dengan pandangan baru yang berkembang di dalam upaya meningkatkan pelayanan publik dengan cara melihat masyarakat tidak hanya sebagai pelanggan melainkan sebagai warga negara yang memiliki negara dan sekaligus pemerintahan yang ada di dalamnya. Pergeseran pandangan ini mengisyaratkan bahwa masyarakat sejak awal harus dilibatkan dalam merumuskan berbagai hal yang menyangkut pelayanan publik, misalnya mengenai jenis pelayanan publik yang mereka butuhkan, cara terbaik untuk menyelenggarakan pelayanan publik, mekanisme untuk mengawasi proses pelayanan, dan yang tak kalah pentingnya adalah mekanisme untuk mengevaluasi pelayanan.

Output pelayanan publik pada RSUD Lanto Daeng Pasewang Kabupaten Jeneponto

Permasalahan utama pelayanan publik pada dasarnya adalah berkaitan dengan 
peningkatan kualitas pelayanan itu sendiri. Pelayanan publik bidang kesehatan merupakan salah satu pelayanan publik dasar. Secara umum, pelayanan publik di Indonesia bernasib sama dengan pelayanan publik lainnya, lekat dengan citra buruk. Namun sejauh ini standar pelayanan publik sebagaimana yang dimaksud masih lebih banyak berada pada tingkat konseptual, sedangkan implementasinya masih jauh dari harapan. Hal ini terbukti dari masih buruknya kualitas pelayanan yang diberikan oleh rumah sakit sebagai penyelenggara layanan publik dibidang kesehatan termasuk yang terjadi pada RSUD Lanto Daeng Pasewang Kabupaten Jeneponto.

Standar pelayanan yang ditetapkan hendaknya realistis, karena merupakan jaminan bahwa janji/komitmen yang dibuat dapat dipenuhi, jelas dan mudah dimengerti oleh para pemberi dan penerima pelayanan. Berdasarkan hasil wawancara dan juga pengamatan dari peneliti dilokasi penelitian, keterbukaan standar pelayanan publik belum realistis dan belum dipublikasikan kepada masyarakat. Pihak rumah sakit belum terbuka mengenai standar pelayanan.

Berdasarkan tanggapan/respon masyarakat tersebut masih mengarah kearah yang negatif, masyarakat masih merasa kurang puas terhadap pelayanan yang diberikan oleh pegawai dan dokter RSUD Lanto Daeng Pasewang kabupaten Jeneponto, dalam sistem penyampaian informasi masih dengan cara yang sederhana yang seharusnya di era globalisasi ini sudah bisa menggunakan sistem informasi yang lebih efektif dan memudahkan masyarakat untuk mengakses setiap kebutuhan informasi.

\section{KESIMPULAN}

Berdasarkan hasil dari wawancara dan pembahasan sebelumnya, maka penulis dapat menyimpulkan hal-hal berikut ini : 1) Penerapan good governance terkait partisipasi sudah terlaksana di RSUD Lanto Daeng Pasewang, namun masih ada yang perlu diajak untuk berpartisipasi yakni partisipasi Masyarakat (NGO). 2) Penerapan good governance terkait transparansi belum terlaksana sepenuhnya di RSUD Lanto Daeng Pasewang. Transparansi anggaran belum terlaksana di RSUD Lanto Daeng Pasewang. 3) Penerapan good governance terkait daya tanggap belum terlaksana di RSUD Lanto Daeng Pasewang. Manajemen RSUD Lanto Daeng Pasewang dianggap belum memiliki daya tanggap yang baik terhadap kebutuhan pasien yakni pelayanan kesehatan dan ketersediaan obat-obatan. 4) Penerapan prinsip good governance terkait akuntabilitas tidak diterapkan oleh pihak manajemen Rumah Sakit Umum Lanto Daeng Pasewang. Tidak adanya keterbukaan terkait anggaran, proses penyusunannya yang tidak transparan hingga berakibat kepada tersangkanya bendahara rumah sakit dan beberapa orang lainnya mencerminkan bahwa akuntabilitas tidak terlaksana di RSUD Lanto Daeng Pasewang. 5) Faktor pendukung dalam proses penerapan prinsip-prinsip good governance adalah faktor kerjasama dan faktor komunikasi. 6) Output sistem pelayanan di RSUD Lanto Daeng Pasewang belum efektif dalam melaksanakan standar pelayanan RSUD mengingat pengurusan administrasi masih lambat serta masih menunggu berhari-hari untuk mendapatkan hasil pemeriksaan.

\section{DAFTAR PUSTAKA}

Adianto, dkk. 2017. Model Penerapan Prinsip Good Governance Dalam Pelayanan Perizinan di Kota Pekanbaru. Administratio: Jurnal Ilmiah Administrasi Publik dan Pembangunan Vol. 8, No. 1: 1-24.

Chaerul, Andi Anas. 2019. Ombudsman Sulsel Sidak pelayanan RSUD Lanto Dg Pasewang Kab. Jeneponto. (Online, https://www.ombudsman.go.id/artikel/ r/artikel--ombudsman-sulsel-sidakpelayanan-rsud-lanto-dg-pasewangkab-jeneponto, diakses 30 Oktober 2020).

Cresswell, John. W. 2017. Research Design: Pendekatan Metode Kualitatif, Kuantitatif, dan Campuran. Yogyakarta: Pustaka Pelajar.

Dwipayana, AAGN Ari. 2003. Membangun Good Governance. Jakarta: Raja Grafindo Pustaka.

Fadilah, Sri. 2011. Analisis Penerapan "Good Governance" Dilihat dari Implementasi Pengendalian Intern dan "Total Quality Management". Prosiding Seminar Nasional Penelitian dan PKM: Sosial, Ekonomi, dan Humaniora Vol 2, No.1: 387-400. 
Handayani, Elpa. 2016. Penerapan Transparansi dan Akuntabilitas Dalam Pelayanan Publik Pada Instalansi Gawat Darurat Rumah Sakit Umum Daerah Sungai Dareh Kabupaten Dharmasraya. Tesis. Padang: Universitas Andalas.

Harbani, Pasolong. 2013.Kepemimpinan Birokrasi. Bandung: CV. Alfabeta.

Idrus, Nurul Ilmi. 2003. To Take Each Other: Bugis Practice of Gender, Sexuality and Marriage. Disertasi. Canberra: Australian National University.

Mardiasmo. 2009. Akuntabilitas Sektor Publik. Yogyakarta: Penerbit Andi.

Merita, Miske. 2015. Implementasi UndangUndang Nomor 25 Tahun 2009 Tentang Pelayanan Publik Untuk Mewujudkan Good Governance Di Bidang Kesehatan (Studi Kasus RSUP Dr. M Djamil Padang). Tesis. Padang: Universitas Bung Hatta.

Moleong, Lexy J. 2010. Metodologi Penelitian Kualitatif. Bandung: Remaja Rosdakarya.

Muljo, Hery Harjono. 2014. Optimalisasi Penerapan Prinsip Good Governance Bidang Akademik Dalam Upaya Mewujudkan Good University Governance. Binus Business Review Vol. 5 No. 1: 91-100.

Napitupulu, Paimin, Pelayanan Publik \& Costomer Satisfaction, PT Alumni, Bandung, 2007.

Ratminto \& Atik Septi Winarsih. 2013. Manajemen Pelayanan. Yogyakarta: Pustaka Belajar.

Sadikin, Rendy Adrikni dan Rahmayunita, Husna. 2020. Pelindung Diri Terbatas, Staf Medis RS di Jeneponto Sampai Galang Donasi. (Online, https://www.suara.com/news/2020/03/ 21/122125/pelindung-diri-terbatasstaf-medis-rs-di-jeneponto-sampaigalang-donasi?page=all, diakses 30 Oktober 2020).

Safrijal, dkk. 2016. Penerapan Prinsip-Prinsip Good Governance Oleh Aparatur Pelayanan Publik Di Kecamatan Kluet Utara Kabupaten Aceh Selatan. Jurnal Ilmiah Mahasiswa Pendidikan Kewarganegaraan Unsyiah. Vol. 1, No. 1: 176-191.
Santosa, Pandji. 2009. Adimnistrsi Publik: Teori dan Aplikasi Good Goverrnance. Refika Asitama: bandung.

Sedarmayanti, 2010, Sumber Daya Manusia dan Produktivitas Kerja ,cetakan kedua, penerbit: Mandar Maju. Bandung.

Sugiyono. 2012. Metode Penelitian Kuantitatif, Kualitatif, dan $R \& D$. Cetakan ke-17. Bandung: Alfabeta.

Surjadi, H. 2009. Pengembangan Kinerja Pelayanan Publik. Malang : Refika Aditama

Suyanto, Bagong dan Sutinah. 2006. Metode Penelitian Sosial. Jakarta: Kencana Prenada Media Group.

United Nations Development Programme (UNDP). (1997). Governance for Sustainable Human Development: A UNDP Policy Document. New York: United Nations Development Programme. 